\title{
Rubinstein, Alissa
}

\section{The 614th Commandment: a documentary play about how American jews feel about Germany today}

Zumhof, Tim [Hrsg.]; Johnson, Nicholas K. [Hrsg.]: Show, don't tell. Education and historical representations on stage and screen in Germany and the USA. Bad Heilbrunn : Verlag Julius Klinkhardt 2020, S. 63-80. - (Studien zur Deutsch-Amerikanischen Bildungsgeschichte / Studies in German-American Educational History)

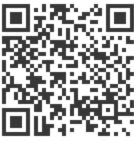

\section{Quellenangabe/ Reference:}

Rubinstein, Alissa: The 614th Commandment: a documentary play about how American jews feel about Germany today - In: Zumhof, Tim [Hrsg.]; Johnson, Nicholas K. [Hrsg.]: Show, don't tell. Education and historical representations on stage and screen in Germany and the USA. Bad Heilbrunn : Verlag Julius Klinkhardt 2020, S. 63-80 - URN: urn:nbn:de:0111-pedocs-205112 - DOI: 10.25656/01:20511

https://nbn-resolving.org/urn:nbn:de:0111-pedocs-205112

https://doi.org/10.25656/01:20511

in Kooperation mit / in cooperation with:

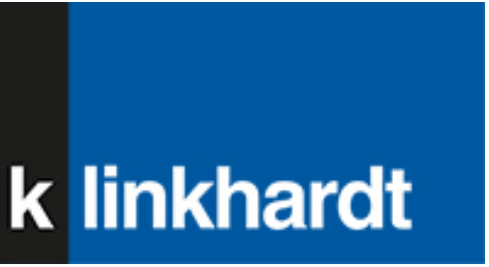

http://www.klinkhardt.de

\section{Nutzungsbedingungen}

Dieses Dokument steht unter folgender Creative Commons-Lizenz: http://creativecommons.org/licenses/by-nc-sa/4.0/deed.de - Sie dürfen das Werk bzw. den Inhalt unter folgenden Bedingungen vervielfältigen, verbreiten und öffentlich zugänglich machen sowie Abwandlungen und Bearbeitungen des Werkes bzw. Inhaltes anfertigen: Sie müssen den Namen des Autors/Rechteinhabers in der von ihm festgelegten Weise nennen. Dieses Werk bzw. der Inhalt darf nicht für kommerzielle Zwecke verwendet werden. Die neu entstandenen Werke bzw. Inhalte dürfen nur unter Verwendung von Lizenzbedingungen weitergegeben werden, die mit denen dieses Lizenzvertrages identisch oder vergleichbar sind.

Mit der Verwendung dieses Dokuments erkennen Sie die Nutzungsbedingungen an.

\section{Terms of use}

This document is published under following Creative Commons-License: http://creativecommons.org/licenses/by-nc-sa/4.0/deed.en - You may copy, distribute and transmit, adapt or exhibit the work in the public and alter, transform or change this work as long as you attribute the work in the manner specified by the author or licensor. You are not allowed to make commercial use of the work. If you alter, transform, or change this work in any way, you may distribute the resulting work only under this or a comparable license.

By using this particular document, you accept the above-stated conditions of use.

\section{Kontakt / Contact:}

\section{peDOCs}

DIPF | Leibniz-Institut für Bildungsforschung und Bildungsinformation

Informationszentrum (IZ) Bildung

E-Mail: pedocs@dipf.de

Internet: www.pedocs.de

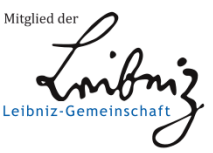




\section{Studien zur Deutsch-Amerikanischen}

Bildungsgeschichte / Studies in German-American Educational History

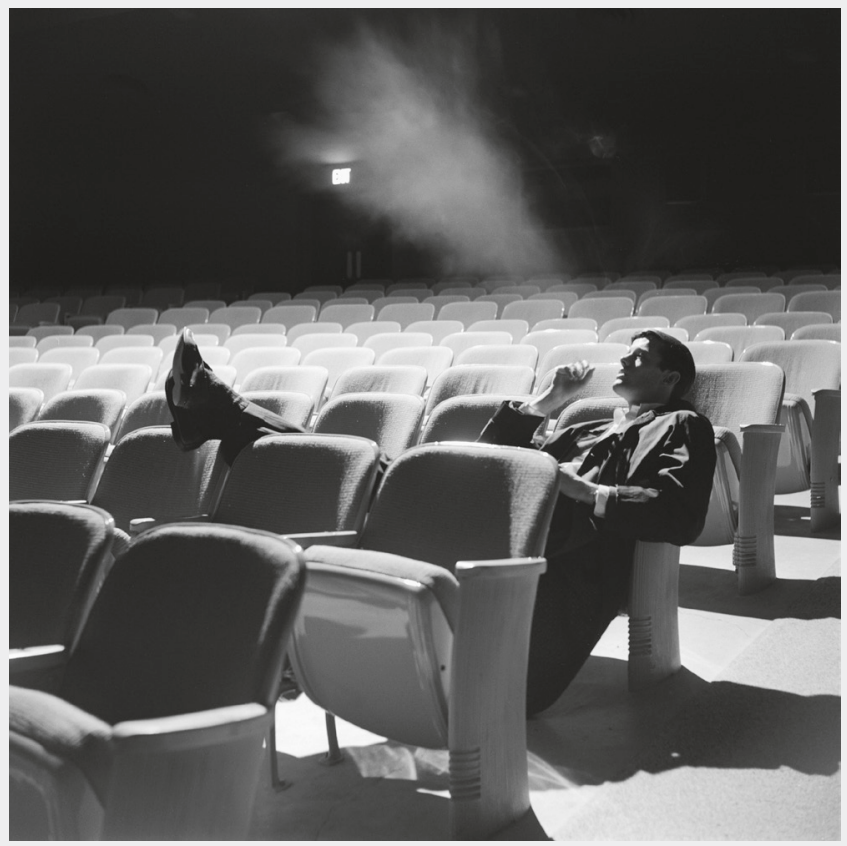

Tim Zumhof

Nicholas K. Johnson (eds.)

Show, Don't Tell

Education and Historical Representations on Stage and Screen in Germany and the USA 


\section{Zumhof / Johnson Show, Don't Tell}


Studien zur Deutsch-Amerikanischen Bildungsgeschichte Studies in German-American Educational History

General Editor Jürgen Overhoff 


\section{Tim Zumhof \\ Nicholas K. Johnson (eds.)}

\section{Show, Don't Tell}

Education and Historical Representations on Stage and Screen in Germany and the USA 
This volume was published in cooperation with the Center for German-American Educational History at the University of Münster.

Titel entstand in Kooperation mit der „Arbeitsstelle für Deutsch-Amerikanische Bildungsgeschichte".

\section{Arbeitsstelle für Deutsch-Amerikanische Bildungsgeschichte}

Dieser Titel wurde in das Programm des Verlages mittels eines Peer-Review-Verfahrens aufgenommen. Für weitere Informationen siehe www.klinkhardt.de.

Bibliografische Information der Deutschen Nationalbibliothek

Die Deutsche Nationalbibliothek verzeichnet diese Publikation in der Deutschen Nationalbibliografie; detaillierte bibliografische Daten sind im Internet abrufbar über http://dnb.d-nb.de.

2020.lg. (C) by Julius Klinkhardt.

Bildnachweis Umschlagseite 1: (C) Francis Miller (1961). Peter Fonda in theater audience seats at Omaha Nebraska Community Playhouse. The LIFE Picture Collection via Getty Images. - The cover photo is used for illustrative purposes only and does not represent an endorsement by the Peter Fonda estate.

Druck und Bindung: AZ Druck und Datentechnik, Kempten.

Printed in Germany 2020.

Gedruckt auf chlorfrei gebleichtem alterungsbeständigem Papier.

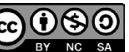

Die Publikation (mit Ausnahme aller Fotos, Grafiken und Abbildungen) ist veröffent-

licht unter der Creative Commons-Lizenz: CC BY-NC-SA 4.0 International

https://creativecommons.org/licenses/by-nc-sa/4.0/

ISBN 978-3-7815-5828-1 Digital

doi.org/10.35468/5828

ISBN 978-3-7815-2397-5 Print 


\section{Table of Contents}

Nicholas K. Johnson and Tim Zumhof

"Are you not entertained?" -

Education, Entertainment, and Historical Representations

on Stage and Screen in Germany and the USA, an Introduction .7

Tim Zumbof

Historical Culture, Public History, and Education

in Germany and the United States of America.

A Comparative Introduction to Basic Concepts and Fields of Research.

Jürgen Overhoff

"Geschichte ist etwas Fließendes."

Lion Feuchtwanger's Changing Understanding of History

and the Role of the Stage: From his Earliest Theatrical Productions

to his Play Waffen für Amerika (1943/44)

Simon Richter

Duell an der Havel:

Fritz von Unruh's Depiction of Eighteenth-Century

Prussian-American Relations

Alissa Rubinstein

The 614th Commandment:

A Documentary Play about how American Jews Feel

about Germany Today

Wolfgang Hochbruck

Living History as an Educational Tool and Method

in North America and Germany

Stephanie Johns

Theatre, Education, and Public History:

Teaching History at the Stratford Festival 
6 Table of Contents

Felix Apel

Hollywood's Influence on the Transmission of Historical Images:

Lars Kraumes' Der Staat gegen Fritz Bauer

Thorsten Carstensen

Learning from John Ford:

History, Geography, and Epic Storytelling in the Works of Peter Handke

Raymond Haberski, Jr.

The Passion of Richard Schickel: What We Expect from War Films

160

Nicholas K. Johnson

"A classroom history lesson is not going to work":

HBO's Conspiracy and Depicting Holocaust Perpetrators on Film

Table of Figures

List of Contributors

Index

Acknowledgements 


\section{Alissa Rubinstein}

\section{The $614^{\text {th }}$ Commandment: A Documentary Play about how American Jews Feel about Germany Today}

How has postwar American Judaism depicted and thought about the Holocaust and Germany? How is that changing as the last survivors pass away - or is it changing at all? These questions form the core of my 2016 play The $614^{\text {th }} \mathrm{Com}$ mandment, which investigates the role and function of history and memory in the American Jewish community, especially regarding how the Holocaust has functioned as something that the community coalesces around to help define its identity.

In my play, I wanted to explore what Esther Jilovsky, Jordana Silverstein, and David Slucki scrutinize in their 2016 book In the Shadows of Memory: The Holocaust and the Third Generation, namely, "the transfer of memory, trauma, history and identity across generations," and more specifically "the aspects of these things that members of the third generation make anew." I zeroed in on what Jilovsky and her colleagues term "inherited memory," with a focus on my own generation: the grandchildren of Holocaust survivors, or what is called the third generation. I chose to focus more precisely on attitudes towards Germany, because learning German and moving to Germany is the way that I personally chose to "make anew" this history for myself. My approach was further influenced by the German diplomat Rolf Schütte, who, as a visiting fellow at the American Jewish Committee in New York from November 2004 to March 2005, said that "American Jewish organizations may have to reinforce their efforts (through education, dialogue, and exchange) to counter a tendency in the American Jewish community to ignore Germany's present and to focus exclusively on its past." ${ }^{2}$ I hoped to be able to contribute to this process of education, dialogue, and exchange with my play. I have experienced a lot of pushback from the Jewish community for my decision to learn German, study in Germany, and ultimately live in the country, particularly from members of the first and second generations: Holocaust survivors and their children. Jilovsky, Silverstein, and Slucki note that while members of the

1 Esther Jilovsky, Jordana Silverstein, and David Slucki. “Introduction: The Third Generation," in In the Shadows of Memory: The Holocaust and the Third Generation, ed. by Esther Jilovsky, Jordana Silverstein, and David Slucki (London \& Portland, OR: Vallentine Mitchell, 2016), 2.

2 Rolf Schütte. "German-Jewish Relations, Today and Tomorrow: A German Perspective." The American Jewish Committee: New York, March 2005, URL: http://deutscheshaus.as.nyu.edu/docs/ IO/6835/German_Jewish.pdf (accessed November 11, 2016), 22. 
second generation received their Holocaust memory from their parents, that is, the first generation, "the third generation's sense of the Holocaust is based on their grandparents as Holocaust survivors, as well as their parents as members of the second generation." The third generation therefore has a "mediated memory of the Holocaust" that unites their connections to the first and second generations, as well as the third generation's engagement with both collective and cultural memory. ${ }^{3}$

My generation's inherited memory has been criticized by the first and second generations for departing from both the second generation's inherited memory as well as the first generation's personal memories. The second generation grew up in close contact with the first generation, while the third generation grew up with far more geographical, chronological, and genealogical distance to the original trauma. My generation also grew up in a post-1970s world of Holocaust consciousness in America, marked by the opening of numerous Holocaust museums, untold numbers of survivor testimony projects, and a huge amount of books, TV documentaries, feature films, and other forms of mediated Holocaust information.

The $614^{\text {th }}$ Commandment looks at all of this from the specific perspective of a member of the third generation conducting interviews with American Jewish people of all ages and backgrounds. Nicole Fox notes that members of the third generation are both familiar with the survivors of the Holocaust and yet "distant enough from the event that they did not experience a great deal of the everyday trauma that the children of Holocaust survivors experienced." ${ }^{4}$ Moreover, the "third generation has also grown up in an environment where there is a plethora of Holocaust literature and discourse," sharply contrasting with the experiences of the generations before. ${ }^{5}$ I believe my being part of the third generation lends my general point of view, as well as my play, an exciting edge, and one that has up until now been mostly neglected in both scholarly and artistic output (Jilovsky, Silverstein, and Slucki's book, for example, was only published in 2016).

More importantly, I chose the medium of theater because I strongly believe that its mixture of creativity and "liveness," with the addition of the research base required by documentary theater, best served my goals. That moment of shared space and time in the theater, with performers and spectators co-creating meaning together, seeking to challenge and understand their own notions of the world, is

3 Jilovsky, Silverstein, and Slucki, "Introduction: The Third Generation," 9.

4 Nicole Fox. "Their history is part of me: Third Generation American Jews and Intergenerational Transmission of Memory, Trauma and History." Moreshet, Journal for the Study of the Holocaust and Antisemitism 8 (2010): 7-35, 7.

5 Fox, "Their history is part of me," 7. 
of deep importance to me. As a producer of The Laramie Project ${ }^{6}$ in high school, I personally experienced the power of theater - specifically politically, socially, and historically engaged documentary theater - to create opportunities for discussion, learning, and growth in local, national, and even international communities. Public historian David Dean, theater historian Yana Meerzon, and performance theoretician Kathryn Prince, the editors of 2015's History, Memory, Performance, the first scholarly work to address the role of theater in public history, define public history quite simply as, "the study of how people consume and shape history." Academic historians frequently criticize public history for being less academically rigorous and overly focused on accessibility to the general public. A similar resistance exists for related forms of public engagement with the past: performance and live theater. Dean, Meerzon, and Prince counter that resistance, noting that "through performance historical consciousness and historical understanding are shaped and nurtured." "Performance can also present opportunities for public history practitioners to "create affective encounters for the public," just like other mediums and methods that are already recognized by academic historians such as history museums or historical fiction.

The $614^{\text {th }}$ Commandment is a documentary play. Broadly speaking, documentary theater is "fact-based performance composed using archival materials such as trial transcripts, official or government documents, iconic visual images or video footage, newspaper reporting, historical writing, and recorded interviews." Fidelity to the source material and levels of "authenticity" vary from playwright to playwright. Documentary theater differs from novels and films, as well as more traditional plays, in that it offers a multiperspective and three-dimensional way to understand real life experiences.

While my play falls under the general heading of documentary theater, its use of transcribed interviews renders it even more specifically an example of verbatim theater. Verbatim theater is a subset of documentary theater that is created using found speech constructed "verbatim" from oral history interviews. Artists often choose to use verbatim theater to publicly consider relevant issues because it reads

6 The Laramie Project is a documentary play by Moisés Kaufman and the Tectonic Theater Project about the 1998 murder of Matthew Shephard in Laramie, Wyoming. Shephard was murdered for being gay, and the play traces the story of the circumstances leading to his death, the ensuing trial, and the effects of these events on the town. The play had its world premiere at the Denver Center Theater Company in 2002.

7 David Dean, Yana Meerzon, and Kathryn Prince. "Introduction" in History, Memory, Performance, ed. by David Dean, Yana Meerzzon, and Kathryn Prince (London: Palgrave Macmillan, 2015), 4.

8 Dean, Meerzon, Prince, "Introduction," 9.

9 Derek Paget. "Documentary Theatre," in The Continuum Companion to Twentieth-Century Theatre, ed. by Colin Chambers. London, 2002, URL: http://www.dramaonlinelibrary.com/genres/documentary-theatre-iid-2482 (accessed November 10, 2014). 
as more authentic for audiences. Verbatim theater takes true words and puts them in a new context.

Categorizing it even further, The $614^{\text {th }}$ Commandment is a staged oral history. The term "staged oral history" positions theater practitioners of this type of work on the border of the oral history and documentary theater worlds. Furthermore, it is not only the creation process that includes a variety of voices, but also the final script. Staged oral history puts a number of community voices onstage at once, displaying not one but many subjects. ${ }^{10}$ The playwright still makes the final editing decisions, however, so all those subjectivities are crafted into the particular story that the playwright wants to tell.

When I embarked on the journey that would become The $614^{\text {th }}$ Commandment, I decided that I did not want to approach the interview process with a narrative structure already laid out. I wanted to capture as much of the diversity of the American Jewish community as humanly possible with respect to age, nationality, birthplace, language background, gender identity, sexual identity, and level of religious observance or non-observance. I generally began an interview by getting consent to turn on the recorder as soon as possible; most of my interviews began with a conversation about the recorder itself, followed by an explanation of my project. Often this would naturally segue into fruitful discussions of my topic. Because I was able to promise my subjects anonymity if they preferred, they could speak freely. Interviews always ended with the interviewee providing verbal consent for me to use their interviews in the play. Anyone who wished to remain anonymous was able to do so.

In addition to deciding whom to interview in the first place, I needed to decide which interviews to transcribe, and then which interviews to use in the piece, i.e. which points of view to focus on. I interviewed many people from a variety of backgrounds: Modern Orthodox, Conservative, Reform, Reconstructionist, secular, atheist, Sephardic, and Ashkenazi. Extreme rightwing, extreme leftwing. I interviewed Iranian Jews, Russian Jews, Greek Jews, Tunisian Jews, Mexican Jews. Gay, straight, bisexual, and transgender Jews. I interviewed a six-year-old. I interviewed a ninety-two-year-old. I interviewed converts and adoptees, survivors and their descendants, people who work at Holocaust museums, Israelis, rabbis, cantors, Hebrew school teachers, public school teachers, and university professors. I did not interview any Jews of sub-Saharan African or East Asian descent, although not for lack of trying. I interviewed rabbis from all the major American denominations, and some of the less major denominations (there is an atheist Society for Humanistic Judaism in Los Angeles that holds services every week but has removed all prayers that mention God). What to do, in a region where there

10 Ryan M. Claycomb. “(Ch)oral History: Documentary Theatre, the Communal Subject and Progressive Politics.” Journal of Dramatic Theory and Criticism 17 (2003): 97-98. 
are enough Moroccan Jews in the San Fernando Valley alone to warrant at least three separate synagogues? Ultimately, I had to come to terms with the fact that I was not going to get anything close to a statistically representative sample of Jewish people living in Southern California. Then again, that was never my goal; from the beginning I had approached the project from the perspective of an oral history playwright more so than that of a traditional historian or sociologist.

I conducted the first round of interviews in the Greater Los Angeles Area between December 2014 and February 2015, and the second in August and September of 2015. Approximately 110 interviews were with individuals, and 15 were with groups of two or more people. Interview length ranged from 20 minutes to over 6 hours, with an average of 45-90 minutes. I also corresponded with several people solely via email. I would estimate that I have about 200 individuals recorded "on tape".

I spent late fall and early winter 2015 sifting through interviews, transcribing, and feeling overwhelmed by the sheer amount of material I had collected. I met Adam Donald, a professional director and actor from New Zealand, at English Theatre Berlin, and we began meeting once a week starting in February. I would send him lightly edited transcripts that we would then read together and discuss, homing in on a narrative and goals together. We were accepted into English Theatre Berlin's Expat Expo in late March, and cast Kellen York and Carrie Getman, both professional American actors based in Berlin, in early April.

The first few weeks of rehearsal consisted primarily of table reads. I would generate raw transcripts and edit them. These were the characters that were delivered to Carrie and Kellen at the table read meetings, where they would then read through them for us out loud. Adam, Carrie, Kellen, and I would debate the merits of the characters and their monologues and together try to distill the essence of each person's story and what pieces seemed the most dramatically viable. Their points of view were immensely valuable. I was also the only person involved in the creative process who is descended from Holocaust survivors, and the only Jew (although Kellen is half-Jewish). My collaborators' more distanced points of view allowed us as a group to find the pieces of text that would work best on stage.

In both the table read rehearsals as well as the regular rehearsals, Adam and I created our own set of rules regarding how to deal with our interview sources as ethically as possible. The main rule was that we had far less leeway with characters whose full names were being used in the script, whereas composite characters and anonymous characters could be tweaked a bit more to fit the requirements of the dramatic structure and the story we wanted to tell.

After we finished the script, I took a figurative step back and Adam assumed a bigger creative role. The actors crafted their characters on their own, primarily using 
Chekhovian character creation techniques, ${ }^{11}$ while Adam took a more Brechtian approach in that he elected to foreground the text and the physical presence of the actors, rather than the characters' emotional lives. The $614^{\text {th }}$ Commandment premiered at $8 \mathrm{pm}$ on 2 June 2016 at a little after 8:00 p.m. in the black box theater at English Theater Berlin | International Performing Arts Center on Fidicinistrasse 40 in Kreuzberg, in front of a sold-out audience of over 150 people.

The audience was able to clearly see that both actors were onstage at the same time for the entire length of the show. They were both dressed in black, and there was no set except for a plain black chair. They gave their monologues primarily to the audience directly, and then shed the character when they moved to the side. The lighting itself was kept simple: warm and unobtrusive. None of the design elements were meant to be symbolic in any way, and there was no specifically defined location or setting for any character.

Additionally, the original production used a style of presentation meant not to distract from the text. The production did not depict the play's section or part titles onstage in any way. Breaks between sections were not delineated, while breaks between parts were made quite clear by the two actors-either one would stop talking and the other would start, or the same actor would stop talking, and then start again as a noticeably different person via changes in physicality, voice, behavior (each character that utilized the chair did so differently), and location on stage. It was deeply important to me that any sense of cultural voyeurism be avoided. As the playwright, I sought to create distance primarily via the fragmented, non-linear structure of the piece, which was meant to be destabilizing, as well as the use of two actors playing multiple characters. I also foregrounded the piece with the knowledge that the play was based on interviews; several characters allude to the original moment of the interview ("After our phone conversation..." or "You and I, by the way..."). The description of the show on the theater's website said that the play was based off of real interviews conducted by the author in Los Angeles and based on her (my) experiences as an American Jewish woman living in Berlin. With that information, the audience could infer that the play is set in Los Angeles, and that when characters say things like "You can start now" or "When you called me..." that they're referring to me, the interviewer.

The $614^{\text {th }}$ Commandment can be staged with anywhere between one and ten actors. As the author, I have included absolutely no stage directions in the text, the intention being that the monologues and dialogues can be better adapted to different performance spaces and contexts, thereby making the piece more accessible and performable for a wide variety of production opportunities, such as schools, community centers, and places of worship, as well as traditional theaters.

11 See Rose Whyman. The Stanislavsky System of Acting: Legacy and Influence in Modern Performance (Cambridge: Cambridge University Press, 2008). 
There are ten characters in total, five women and five men. The women are Katie, a palliative care social worker at a Jewish hospital; Rachel, a rabbinic school student; Brenda, a recently retired administrator for a Jewish social services organization; Karen, a suburban nurse; and Doris Wise Montrose, a child of Holocaust survivors who hosts politically right-leaning lectures and runs an organization called Jews Can Shoot. The men are Yonatan, a Hebrew school teacher; Daniel, a Modern Orthodox rabbi and hospital chaplain; Steve, Karen's husband; Michael Berenbaum, the creator of the United States Holocaust Memorial and Museum (USHMM); and Bernie Rosenzweig (Z”L), a German-Jewish immigrant from Brooklyn. I chose these people because they showed the widest range of common points of view I came across regarding Germany during my research process, from the most relaxed to the most extreme, and also made a number of intriguing comments regarding Holocaust memory and contemporary American Judaism. The three characters whose full names appear in the script are real people. They gave me verbal permission during their recorded interviews to use their full real names in the piece. As is made clear in the play, Doris Wise Montrose specifically forbade me from using any piece of her interview if I did not also use her real name. As the creator of the USHMM, and a preeminent Holocaust historian, Michael Berenbaum was an important authenticating voice in the play. His role in creating the USHMM and his stance on the universalist approach to Holocaust history is known to those in the history community. While Berenbaum does not specifically identify himself until the very end, his presence adds a sense of validation from the traditional academic history and public history communities. Bernie Rosenzweig also makes it clear in the play why he would like his real name to be used - it is a form of protest. He does not want to hide. Like Doris, he fully stands behind what he says.

The remaining seven characters are pseudonyms. Brenda, Yonatan, Karen, and Steve are all based on one real person each who simply preferred to remain anonymous, while Daniel, Rachel, and Katie are composite characters.

The script is organized into five sections, entitled "Arrival," "Going," "Dealing with It," "614," and "Tradition." Each section is made up of between eight and thirteen parts, and each of those parts also has a title. The parts range in length from one sentence to one paragraph to one page. For the most part, the titles of the moments reflect the topic of each moment, though in some cases the title is more symbolic. To grasp the structure of the play, it is helpful to examine a list of the play's "scenes":
I. Arrival
1. Something weird (Katie)
2. Blessed (Yonatan)
3. What we know (Karen and Steve) 
4. The "h"/How we got out (Bernie Rosenzweig)

5. The original trauma (Katie)

6. I'm just Jewish (Daniel)

7. Porn (Doris Wise Montrose)

8. The world that they had lost (Michael Berenbaum)

9. Association (Rachel)

10. Recognize the signs (Daniel)

11. The obligation of every child of survivors (Doris Wise Montrose)

12. Consumed (Michael Berenbaum)

\section{Going}

1. Invitation (Bernie Rosenzweig)

2. Some kind of blasphemy (Karen and Steve)

3. Realer (Daniel)

4. Thoroughly misbehaving (Michael Berenbaum)

5. A genetic thing (Brenda)

6. Reaction (Bernie Rosenzweig)

7. Europe (Doris Wise Montrose)

8. A conversation (Bernie Rosenzweig)

9. Liz, or why I am not afraid of the German language (Rachel)

10. Very strange (Bernie Rosenzweig)

11. No strong feelings either way (Brenda)

12. The second time I learned it was a thing (Rachel)

13. October (Yonatan)

\section{Dealing with it}

1. If you scratch a non-Jew...(Daniel)

2. You and I and us (Doris Wise Montrose)

3. My Israel thing (Yonatan)

4. The easiest way to get booed by a Jewish audience (Michael Berenbaum)

5. Community (Rachel)

6. A sense of strength (Doris Wise Montrose)

7. A broad view (Rachel)

8. A biblical view/I guess it would be good if they lose (Daniel)

9. Trust (Karen and Steve)

10. Horns (Daniel)

11. Tell me the truth (Karen and Steve)

12. When I teach kids about the Holocaust (Yonatan)

13. I'm a liar! (Karen and Steve) 


\section{The 614th Commandment $\mid 71$}

\section{614}

1. Real (Yonatan)

2. Repeat (Katie)

3. Peace and love, except for Germans! (Karen and Steve)

4. The buddy system (Daniel)

5. Escape (Brenda)

6. Holocausted out (Michael Berenbaum)

7. I don't need to hear anything/ A long memory

(Doris Wise Montrose)

8. Genesis (Daniel)

\section{Tradition}

1. Moving on (Karen and Steve)

2. Too much (Daniel)

3. The language (Karen and Steve)

4. People who do bad things (Yonatan)

5. The $614^{\text {th }}$ commandment (Rachel)

6. Danger (Doris Wise Montrose)

7. Clarity (Michael Berenbaum)

8. The ultimate professional (Karen and Steve)

9. The ending (Daniel)

10. Mom (Doris Wise Montrose)

11. What makes this night different from all other nights? (Michael Berenbaum)

12. That's it (Brenda)

13. Numbers (Yonatan)

14. The god thing (Rachel)

15. Learn something (Daniel)

16. I want you to get it right (Doris Wise Montrose)

17. \#lol (Michael Berenbaum)

The parts are all monologues (except for the dialogue between Karen and Steve, who always appear together, even when Karen is the only one who speaks). Lisa Hays reminds us that, "to truly understand the process of theatricalizing oral history, it is important to see how the playwright has shaped the text-how characters are identified and introduced, how transitions are created, how time is handled, how one character's story is punctuated by the line of another character..." ${ }^{\prime 2}$

12 Lisa Hays. "Theatricalizing Oral History: How British and American Theatre Artists Explore Current Events and Contemporary Politics in the Journey from Interview to Performance" (Phd. diss., The State University of New York at Buffalo, 2008), 12. 
The script of The $614^{\text {th }}$ Commandment is painstakingly constructed. Where the characters are speaking to the interviewer/audience, where they are speaking to another character onstage, when they hear what a previous character just said and comment on it, when they argue, when they interrupt, when they deliberately try to provoke, and when they deliberately try to lighten the mood - these instances are all carefully planned.

The monologues in The $614^{\text {th }}$ Commandment are arranged so that each monologue reflects on the previous one in some way, providing additional information, complementing what was said, or directly contradicting it for effect.

The idea is that the play teaches the audience how to watch it; when it begins it can be hard to understand what is going on, since most of the action of the piece is subtle, to be found in the juxtapositions between characters' words - and in our production all ten characters were played by two actors. My goal was to start slowly, introducing the characters, themes, and structure of the play, before speeding up the rhythm of the piece and diving into more difficult material. I wanted the piece to feel more chaotic and confusing, deliberately reflecting the fragmented nature of memory.

The first section, "Arrival," is both an arrival in Germany, an introduction to each character (except Brenda, who first appears in the second section), and a primer on the piece's structure. The first monologue, for example, "Something weird," is a literal arrival in Germany: Katie sets the scene by recounting what it felt like to fly into Berlin for the first time. She remembers that it felt both "creepy" and "familiar," and jokingly refers to the idea of a "communal unconscious" that brought her back to the 1940s, almost like a time machine - a reference to the concept of a collective Jewish memory - but acknowledges that both Germany's familiarity and its creepiness probably have more to do with the media representations and cultural memory of "Germany" with which she grew up. The vacillation between the creepy and the familiar, the influence of a "communal unconsciousness" and the influence of popular representations of history like movies and books are recurring themes throughout the play.

The second monologue of the play, "Blessed," addresses me/the audience directly and underscores the main topic. Yonatan, a gregarious, larger-than-life personality based off the youth engagement director at my parents' synagogue, marches in and tells us his birth sign before chuckling to himself and saying, "No, I'm kidding, you're doing the thing, Germany. We can start now, I'm sorry." This form of direct address to "you," originally meaning me, the interviewer, during the actual interview, but in performance addressed directly to the audience, is meant to be jarring. It is intended to remind audience members of the original interviews that the monologues and dialogues are taken from, and also to remind them that everything they are hearing is being filtered through my lens. I am not purporting to present an "objective" presentation of my "objective" research. These interviews 
were deeply personal and subjective due to my family background and personal views, and the audience should never feel like they are receiving some sort of purely objective history lesson.

The next characters the audience is introduced to, in "What we know," are Karen and Steve, a suburban couple in their mid-sixties who are actually good friends of my parents whom I have known for years. They are the only two characters who fully interact with one another, and their connection is the beating heart of the show. Karen and Steve operate as a team, feeding off one another and finishing each other's sentences. They are very silly and light-hearted, but almost immediately betray a tinge of darkness beneath the jokes. The intention is that the audience laughs at/with them, but it is an uncomfortable laugh, because there is a lot of honesty and truth behind what they are saying. Their views on Germans are emblematic of what I found in my interviews with second generation American Jews, and their descriptions of "what [they] know" set a baseline for the play as a whole.

The next character to be introduced is Bernie Rosenzweig, in "The ' $h$ '/How we got out." Bernie is the oldest character in the show and the only one who could be construed as a Holocaust survivor. He left Dortmund, Germany, for New York City as a child and lost a number of family and friends in the Holocaust. He went back to Germany as part of the Invitation Program for Former Persecuted Citizens of Dortmund. Bernie is a very difficult character and someone we struggled mightily with during the workshop and rehearsal process. Bernie was clearly marked by a deep sense of loss, and along with that came a very intense and at times malicious bitterness. Especially given that the show was going to premiere in Germany, I thought it would be especially poignant to have the oldest character be a German who had fled as a child. He comes at the material both as an old man reflecting on his life, someone who knows the story of how his family escaped and how he grew up, and as a young boy caught up in events he only partly understands-a young boy who used to have a different name and then lost his " $h$ " when he arrived as a refugee in a new country (his name was originally spelled "Bernhard").

Generally speaking, all of the interview material had to be carefully organized to relieve the audience from the emotional intensity of the play. Lighter scenes, designed for comic relief but still relevant to the topic, had to be interspersed at the appropriate moments throughout the script to provide breathing room for the audience. We knew from the beginning that Bernie was a powerhouse character whose story and general attitude would be shocking. We also knew that, given that this script was being created for a performance in Germany, we risked completely alienating our audience members by having an angry and bitter Holocaust survivor just verbally attack them for the duration of the play. We had to strike a balance, shocking the audience, but not to the point of disengagement. We ended 
up cutting Bernie's monologues down to the bare minimum and concentrating them at the beginning of the show for this reason.

The next character to be introduced, after another monologue from Katie ("The original trauma"), is Daniel, who is a composite of a Modern Orthodox Jewish chaplain of a major Jewish hospital in Los Angeles, a Conservative rabbinic intern, the well-known Conservative rabbi David Wolpe, and the rabbi emeritus of the biggest Reconstructionist synagogue in the world, Steven Carr Reuben. In his introductory monologue, "I'm just Jewish," the audience meets their first rabbi. Daniel goes on to both humorously and quite eloquently discuss his experiences with anti-Semitism and his struggle with how to bring together his knowledge of history and awareness of current events with the hope that he finds in traditional Jewish life and texts.

He is followed by Doris Wise Montrose and "Porn." Doris is the founder and president of Children of Jewish Holocaust Survivors, a Los Angeles-area non-profit that seems to consist entirely of Doris and her Jews Can Shoot organization (tagline: "Nothing Says Never Again Like An Armed Jew," logo: a Star of David made out of rifles). Doris is, for me, easily the most captivating character in the show. She is direct, and intelligent, and funny, and, frankly, very scary. She speaks poignantly of her family's experiences in the Holocaust. Her anger at the failure of the international community to prevent war crimes and genocides post-World War II is palpable, and yet her way of fighting against that, her way of reacting to her background and her history, is extreme and radically different from the paths of the other characters in the show.

The Doris that came through both in the original interview as well as in the final performance is a person deeply psychologically affected by the Holocaust experiences of her parents. Her need is simple: to stay safe. She is upset by the perceived weakness of her parents' generation, their inability to fight back, and so she wants to enable future possible victims to fight back. Her major speech on genocides that came after the Holocaust is telling. She speaks powerfully and with great passion about preventing future trauma, about how peoples' desire to extract meaning from tragedy prevents them from actually, physically doing something to prevent tragedy in the present moment.

Next, Michael Berenbaum is introduced in "The world that they had lost." Berenbaum takes a universalist approach to the Holocaust and invokes the metaphor of the Jewish holiday of Passover, a ritualized remembering of the Exodus from Egypt. Judaism as a religion encourages individuals to nurture personal and deeply intimate connections to historical events that they did not themselves experience. That personal connection can lead to a pervading anxiety, but Berenbaum also argues that when re-imagined, the same connection that sometimes encourages a form of PTSD in the greater Jewish community can be used for positive future change, like in the contemporary uses of the Passover story. In the final lines of the 
play, Berenbaum directly challenges both myself as interviewer and the audience as viewers of the play to do something with what I/they have just heard. He specifically says, "Let's see what you do with it," where "it" refers to both the discussion he and I just had, as well as the play that the audience has just seen. I conceive of this last line as an invitation to critically reflect on the points the play brings up and to potentially use those reflections in some positive way.

Rachel is the next character introduced, with "Association." She has a much lighter personality and point of view on the themes of the play, specifically because she was pointedly not raised to be afraid (except, of course, for what she tells us in this first monologue, although even her story about being afraid as a child that her father was going to be taken away by the Nazis is played for laughs). She grew up with a German best friend, is the product of an interfaith marriage, and is becoming a rabbi because she genuinely loves Jewish tradition, specifically the focus on social justice and community, and wants to share it.

As Rachel tells us, "the German language has never been scary to me, the people have never been scary to me" - specifically because she grew up with a German best friend and therefore knows an individual German in a context not influenced by the Holocaust. The irony is clear when, in reference to her German best friend's grandma, she says, innocently, happily, "She's exactly what you would think, right?" - and then goes on to talk about how she's just "a ball of grandma" and cooks "downhome German foods." Rachel is not naïve, but she does not see a reason to suffer under the burden of history. She is a truly contemporary, twenty-first century young Jewish woman, aware of and yet unburdened by the Holocaust. She is also the character who explains the play's title to us by way of mentioning Emil Fackenheim, ${ }^{13}$ but if anything, she seems exasperated by the idea of being commanded to constantly remember. Rachel is used like this throughout the play; she is aware of but unburdened by history and often functions as an escape valve for the audience, such as when she breaks up Bernie's haranguing by deeply sighing and laughing. She is also often placed in direct confrontation with Doris, who is another strong female character.

The final character to be introduced, in the middle of the second section, "Going," is Brenda. Her character is entirely composed from one interview with a recently retired social worker who worked exclusively with Holocaust survivors in Los Angeles. Brenda is also a lighter character who provides historical background as well as humor.

After "Arrival" introduces us to the play's structure, themes, and characters, "Going" delves into the idea of what it means to go to Germany as an American Jew

13 There are 613 mitzvot, or commandments, in the Torah; Fackenheim's $614^{\text {th }}$ commandment is to not grant Hitler a posthumous victory by abandoning Judaism. See Emil L. Fackenheim, To Mend the World (Bloomington, Indiana: Indiana University Press, 1994), 213. 
in the twenty-first century. Bernie's experiences in Germany form the core of this section, but we also hear, for example, from Doris, who can only associate Germany, and Europe as a whole, with death and destruction; Rachel, who has visited Germany and feels positively towards it; and Brenda, who admits that she grew up thinking Germany was evil and has never been there, but also does not have particularly strong feelings about it, even though she spent her career working with Holocaust survivors.

The third section, "Dealing with it," looks more deeply at Holocaust memory in the American Jewish community in the twenty-first century. At this point the oldest character, Bernie, no longer appears in the play - his absence is intentional and meant to be symbolic - and the second and third generation voices take over. Issues addressed in this section range from contemporary anti-Semitism to Holocaust education in schools to Karen's darkly funny fantasy about torturing her elderly German surgery patients to find out what they were doing during World War II.

The fourth section, "614," examines some of the repercussions of the anxiety surrounding memory of the Holocaust in the Jewish community. In addition to Daniel admitting how difficult it can be to work with Holocaust survivors in the hospital and Brenda categorizing her retirement from her job working with survivors as her own personal escape, this section also features Michael Berenbaum's honest account of the effects his work on the United States Holocaust Memorial and Museum had on his young children and Doris' impassioned plea against postWorld War II genocides. "614" closes with a Biblical interlude from Daniel.

The fifth and final section is "Tradition." Berenbaum hopes that memory of the Holocaust will ultimately be positively integrated into Jewish tradition in the way that the Exodus from Egypt and Passover function within the liturgical calendar, Daniel suggests that Germans learn more about Judaism, the audience finds out that Doris's Holocaust survivor mother has dementia and has been upstairs the entire time, Doris demands that her real name be used in the play, and, finally, Berenbaum slyly asks what the audience is going to do with the information they have just been given.

The $614^{\text {th }}$ Commandment explores the idea that, in a way, Germany itself, and sometimes also individual German people and the German language, have also become stand-in symbols for evil. In particular, the piece's humor - for example, Yonatan's slow and deliberate eating of a banana while discussing how he teaches young students about the Holocaust - is intended to help audience members take a step back and examine these common tropes from a more distanced perspective. I was inspired by cultural historian Diana Popescu's discussion of Yael Ronen's play Third Generation (2009), in which Popescu contends that Ronen uses "laughter to draw attention to the ritualized ways in which the Holocaust is discussed and continues to affect younger generations." Ronen uses humor "as a means to 
create distance from the processes of 'working through' undertaken by the second generation," the goal being to foreground the more critical and detached perspective of the members of the third generation. ${ }^{14}$

I deliberately chose to prioritize these second- and, especially, third-generation voices in my piece. Jilovsky observes that, as the last survivors pass away, "the narratives of nonsurvivors begin to take precedence, indicating a shift from survivor memory to nonsurvivor memory." Additionally, the fact that the third generation represents "the last living link to survivors who nevertheless rely on imagination to witness the Holocaust" is yet another shift, "a crucial one, in which remnants of the Holocaust are still evident, but which are increasingly dominated by later generations' perspectives on the past." ${ }^{15}$

In depicting members of various generations but prioritizing the voices of the second and third generations, with a special emphasis on the third generation, The $614^{\text {th }}$ Commandment sought to make this generational turnover the subject of discussion. Throughout the research, interview, workshop, and script creation process, I intended to question these collective memories, specifically regarding attitudes towards Germany. Ultimately, I wanted to stress that these attitudes towards contemporary Germany are symptoms of a bigger issue, namely how we remember and use the Holocaust today within the Jewish community.

The $614^{\text {th }}$ Commandment seeks to examine how the stories we tell about the Holocaust - in the media, in our private lives, in our families, in our communities - develop and change. The play demonstrates that succeeding generations feel differently than earlier ones, but the anxiety concerning Holocaust memory, and with it the demonization of Germany and Germans, continues to be passed down to a certain extent. As Brenda says, even in her postwar secular Jewish community in New York City, she felt that Germans and Germany were evil and scary. She does not recall anyone saying this directly, but the feeling was somehow just there. This feeling has certainly lessened over the years, but my personal experiences learning German, living in Germany, and dealing with anxious, fearful, and at times hateful reactions from members of the American Jewish community to my choices show that we are still dealing with it today. American Jewish millennials in the English Theater Berlin audience in June laughed at depictions of American Jews in their 60s making fun of the German language as intrinsically scary, but they recognized that point of view from their own lives. That is why I embarked on this project in the first place, and that is what I hope audience members walked away from the show thinking about.

14 Diana I. Popescu. "Performance, Memory and Identity: The Israeli Third Generation in Yael Ronen's Third Generation Play (2009)," in In the Shadows of Memory: The Holocaust and the Third Generation, ed. by Esther Jilovsky, Jordana Silverstein, and David Slucki (London \& Portland, OR: Vallentine Mitchell, 2016), 221.

15 Jilovsky, Remembering the Holocaust, 145. 
Anecdotal information, including emails and verbal feedback received after the performance, indicates that audience members had powerful reactions to the show. Dr. Uta Larkey, an associate professor of German at Goucher College in Baltimore, Maryland whose research focuses on oral history and memory of Holocaust survivors and German-Jewish studies, wrote to tell me about her "rave review" of the show. ${ }^{16}$ Dr. Jacob S. Eder, a research associate in the contemporary history department at Friedrich Schiller University Jena who recently finished a book about the significance of Holocaust memory for German-American relations since the late 1970s, wrote that, "[he] found [my] play highly intriguing. It also reminded [him] of a few conversations [he had] had in the US [himself]." ${ }^{17}$ I also received a range of feedback from people who were unable to see the live performance, but who did read the script and/or watch the video of the performance. Rabbi emeritus Steven Carr Reuben of Kehillat Israel Reconstructionist Synagogue in Pacific Palisades, California, whom I interviewed for the project and whose words appear in parts of both the rabbi and rabbinic intern characters, read an earlier version of the script and said, "I just read the play and it's fantastic. You did a wonderful job of putting together a totally compelling and believable range of attitudes and emotions about Germany, Germans and how we filter the Holocaust through the lens of our own personal experiences." ${ }^{18}$ David Kinberg, my high school European history teacher and a Reform Jew, was also interviewed for the project. In response to the video, he said, "This was awesome! [...] I am so impressed with your dialogue. You actually expressed a lot of the sentiments I have personally had." ${ }^{19}$

Doing the show in Germany, for a German (and international) audience, is different than doing the show in the United States. It means something different to have a group of Jewish voices coming together to discuss what they think about Germany in Germany. In the United States, the show would be more likely to produce a discussion on how people agree with various points of view in the show, whereas Germans told me that they found the show compelling precisely because they had never heard these sorts of viewpoints before and did not know they existed, or they did know but thought people they knew did not, and they thought being exposed to a variety of contemporary American Jewish voices was important for Germans.

It is also interesting to note that many people fixated on knowing the personal biographies of the director and the actors and were shocked to find out that only one of them was (half) Jewish. This speaks to the fact that people often assume

16 Dr. Uta Larkey, e-mail message to author, June 18, 2016.

17 Dr. Jacob S. Eder, e-mail message to author, June 3, 2016.

18 Rabbi Steven Carr Reuben, e-mail message to author, May 16, 2016.

19 David Kinberg, e-mail message to author, August 26, 2016. 
that this sort of material must be very personal for everyone involved and cannot "just" be theater and stand on its own. This is why I did not want to perform it myself. It's also noteworthy that the non-Jewish actress expressed concerns about being perceived as taking ownership of stories and a history that did not "belong" to her, while the half-Jewish actor said that his Jewish mother was very excited that he was working on something more "meaningful" than usual.

Ultimately, I wanted to show how the American Jewish community is processing its history, prompt audience members to consider why the community is processing it that way, and encourage discussion on how changes could be made to that process in the future. The $614^{\text {th }}$ Commandment will ideally have future performances that will mean different things to different audiences. It is a very flexible piece, requiring at minimum one actor and very little in the way of set, costumes, or lighting. I see possibilities for the piece in educational theater, museum theater, and in community theater, particularly at synagogues and Jewish community centers. In order for the play to reach a wider audience in Germany it will have to be translated. I believe there could also be intriguing educational applications of this play in a German school context.

I hope The $614^{\text {th }}$ Commandment has encouraged Germans, Jews, and everyone else who has seen or read it to think a bit more critically about how the Holocaust is remembered and how it is remembered affects our daily lives and interactions with one another. I also hope that, in a small way, The $614^{\text {th }}$ Commandment has contributed to the need for dialogue and can continue to do so in the future.

\section{Cited works}

Claycomb, Ryan M. "(Ch)oral History: Documentary Theatre, the Communal Subject and Progressive Politics.” Journal of Dramatic Theory and Criticism 17.2 (2003): 95-122.

Dawson, Gary Fisher. Documentary Theatre in the United States: An Historical Survey and Analysis of Its Content, Form, and Stagecraft. Westport, CT \& London: Greenwood Press, 1999.

Dean, David, Yana Meerzon, and Kathryn Prince (ed.). History, Memory, Performance. London: Palgrave MacMillan, 2015.

Dolan, Jill. "The Laramie Project: Rehearsing for the example," in Utopia in Performance: Finding Hope at the Theater. (Ann Arbor: University of Michigan Press, 2005), 113-139

Eder, Dr. Jacob S., e-mail message to author, June 3, 2016.

Fackenheim, Emil L. To Mend the World. Bloomington, Indiana: Indiana University Press, 1994.

Fox, Nicole. "Their history is part of me: Third Generation American Jews and Intergenerational Transmission of Memory, Trauma and History." Moreshet. Journal for the Study of the Holocaust and Antisemitism, 8 (2010): 7-35.

Hays, Lisa. "Theatricalizing Oral History: How British and American Theatre Artists Explore Current Events and Contemporary Politics in the Journey from Interview to Performance" (Phd. diss., The State University of New York at Buffalo, 2008).

Jilovsky, Esther. Remembering the Holocaust: Generations, Witnessing and Place. London \& New York: Bloomsbury Academic, 2015.

Jilovsky, Esther, Jordana Silverstein, and David Slucki (ed.). In the Shadows of Memory: The Holocaust and the Third Generation. London \& Portland, OR: Vallentine Mitchell, 2016. 
Kinberg, David, e-mail message to author, August 26, 2016.

Larkey, Dr. Uta, e-mail message to author, June 18, 2016.

Lazarus, Eleanor S. to Dagmar Celeste, Dec. 17, 1987, AJC Archives, New York.

Paget, Derek. "Documentary Theatre," in The Continuum Companion to Twentieth-Century Theatre, ed. by Colin Chambers. (London, 2002), URL: http://www.dramaonlinelibrary.com/genres/documentary-theatre-iid-2482 (accessed November 10, 2014).

Popescu, Diana I. "Performance, Memory and Identity: The Israeli Third Generation in Yael Ronen's Third Generation Play (2009)," in In the Shadows of Memory: The Holocaust and the Third Generation, ed. by Esther Jilovsky, Jordana Silverstein, and David Slucki (London \& Portland, OR: Vallentine Mitchell, 2016), 209-226.

Reuben, Rabbi Steven Carr, e-mail message to author, May 16, 2016.

Schütte, Rolf. "German-Jewish Relations, Today and Tomorrow: A German Perspective." The American Jewish Committee. New York, March 2005, URL: http://deutscheshaus.as.nyu.edu/docs/ IO/6835/German_Jewish.pdf (accessed November 11, 2016).

Whyman, Rose. The Stanislavsky System of Acting: Legacy and Influence in Modern Performance. Cambridge: Cambridge University Press, 2008. 